\title{
A giant lipoma
}

\section{Tunde Abdulsalam, Christopher Nnaemeka Osuafor, Mary Barrett, Toddy Daly}

Department of Medicine, Mater Misericordiae University Hospital, Dublin, Ireland

\section{Correspondence to} Dr Tunde Abdulsalam, abdulst@tcd.ie

Accepted 23 August 2015

\section{DESCRIPTION}

A 46-year-old woman presented with a large painless mass, present for over 10 years, on her right mid-lower back. However, it had increased in size over the past 3 years.

She was a heavy-smoker, with a history of chronic obstructive airway disease.

On examination, there was a large pedunculated mass located on her right mid-lower back (figure 1A-C, lateral view; figure $1 \mathrm{D}, \mathrm{E}$, close-up view). It was firm to the touch and non-tender. She had no other skin lesion and there were no palpable nodes. The rest of the examination was normal.

Given the clinical findings, an MRI was performed due to concern for an underlying sarcoma (figure 2A, B, MRI-sagittal view; figure 2C, MRI axial view) reported a $19 \times 17 \times 6.7 \mathrm{~cm}$ (Craniocaudal $\times$ transverse $\times \mathrm{AP}$ ) mass at mid-thoracic to upper lumbar area. It demonstrated uniformly high T1 and T2 signals and was suppressed on the T1 fatsuppressed sequence. There was no abnormal enhancement and no communication between the
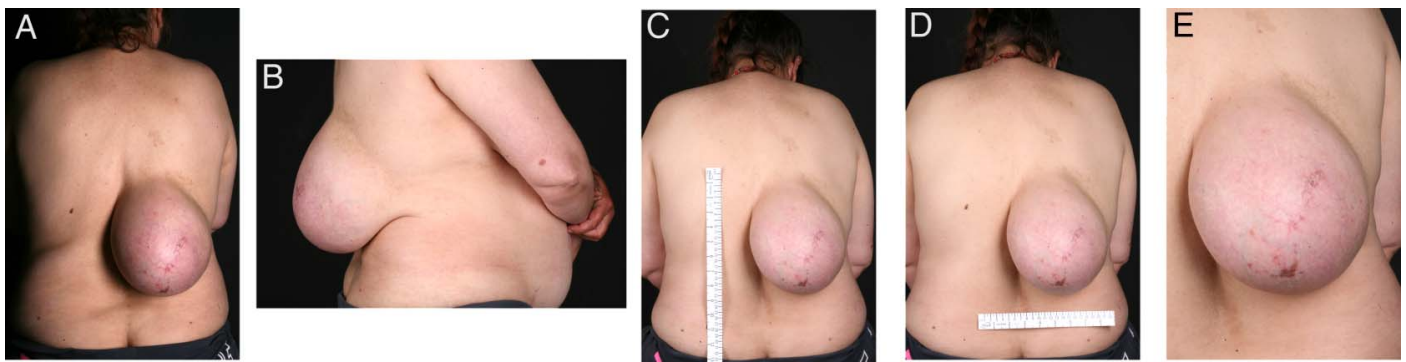

Figure 1 Photographs showing a large pedunculated mass measuring $19 \times 17 \mathrm{~cm}(A-C$, lateral view; $D$ and $E$, closer view).
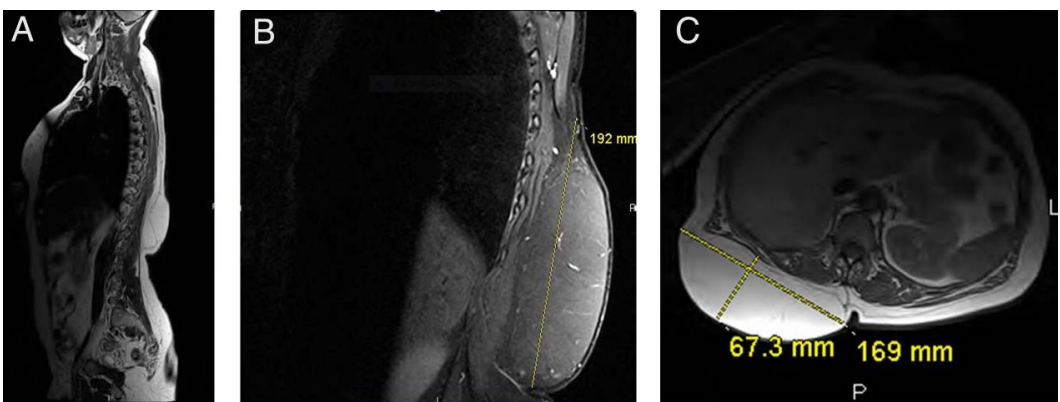

Figure 2 MRI reported a $19 \times 17 \times 6.7 \mathrm{~cm}$ (craniocaudal $\times$ transverse $\times$ AP) mass extending from mid-thoracic to upper lumbar levels. It demonstrated uniformly high T1 and T2 signal and was suppressed on the T1 fat-suppressed sequence. There was no abnormal enhancement and no communication between the mass and the underlying spine (A, sagittal view; B, close sagittal view; $C$, axial view).
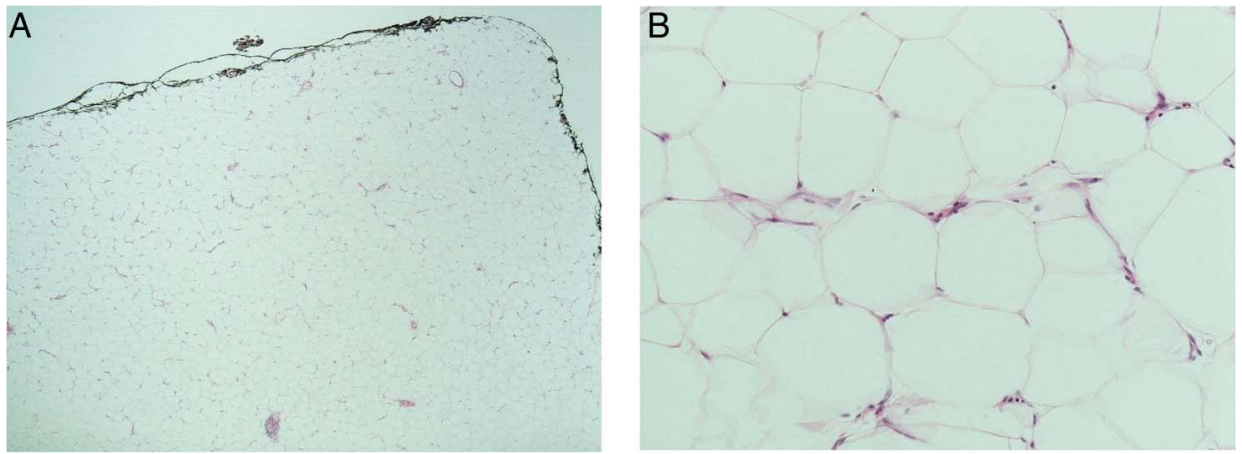

Figure 3 Histology—sheets of mature adipose tissue in keeping with a benign lipoma (A, low power; B, high power). 
mass and the underlying spine. Histology (figure 3A, low power; figure $3 \mathrm{~B}$, high power) reported findings consistent with a lipoma.

Lipomas are benign neoplasms made up of adipocytes. They can occur on any part of the body but frequently occur in the trunk and upper extremities. They are likely to present in the 40-60-year age group. ${ }^{1}$ They are usually painless, soft and small, at about $1 \mathrm{~cm}$, but can be giant lipomas greater than $10 \mathrm{~cm}$ in size. ${ }^{1}$ They are commonly diagnosed clinically, but an

\section{Learning points}

- Lipomas are usually small in size, with a soft consistency, but, in some cases, they can be relatively firm and impressive in size.

- While lipomas can be clinically diagnosed, a differential diagnosis of liposarcoma must be considered in a firm, painless, enlarging subcutaneous lesion. This is an indication for biopsy.

- MRI is a useful imaging modality in distinguishing lipomas versus liposarcomas. indication for biopsy would include a firm, rapidly enlarging mass. Lipomas can be managed conservatively or excised. ${ }^{1}$ Other treatments include liposuction. ${ }^{2}$ Transformation of lipomas into liposarcoma is rare. Findings indicative of liposarcoma on MRI include male sex, advanced age, thick septa, nodularity, reduced fat composition and invasion of underlying tissue. $^{3}$ Histologically, main features of liposarcomas include immature adipocytes and multivacuolation with indented and hyperchromatic neuclei. ${ }^{4}$

Acknowledgements The authors wish to thank the Mater Hospital Clinical Photography, Pathology and Radiology Departments.

Competing interests None declared.

Patient consent Obtained.

Provenance and peer review Not commissioned; externally peer reviewed.

\section{REFERENCES}

1 Salam GA. Lipoma excision. Am Fam Physician 2002;65:901-4.

2 Wilhelmi BJ, Blackwell SJ, Mancoll JS, et al. Another indication for liposuction: small facial lipomas. Plast Reconstr Surg 1999;103:1864-7.

3 Kransdorf MJ, Bancroft LW, Peterson JJ, et al. Imaging of fatty tumors: distinction of lipoma and well-differentiated liposarcoma. Radiology 2002;224:99-104.

4 Weiss SW. Lipomatous tumors. Monogr Pathol 1996:38:207-39.

Copyright 2015 BMJ Publishing Group. All rights reserved. For permission to reuse any of this content visit http://group.bmi.com/group/rights-licensing/permissions.

BMJ Case Report Fellows may re-use this article for personal use and teaching without any further permission.

Become a Fellow of BMJ Case Reports today and you can:

- Submit as many cases as you like

- Enjoy fast sympathetic peer review and rapid publication of accepted articles

- Access all the published articles

- Re-use any of the published material for personal use and teaching without further permission

For information on Institutional Fellowships contact consortiasales@bmjgroup.com

Visit casereports.bmj.com for more articles like this and to become a Fellow 